\title{
First report of Borna disease virus antibodies in breeding and sport horses in Spain.
}

\author{
Fátima Cruz-López ${ }^{1}$, Susanne Schmid ${ }^{2}$, Eliazar Camino ${ }^{1}$, Friedemann Weber $^{2}$, Paloma \\ Fores $^{3}$, Sergio Gonzalez ${ }^{1}$, Lucia de $\mathrm{Juan}^{1}$, and Matthias König ${ }^{2}$ \\ ${ }^{1}$ Universidad Complutense de Madrid \\ ${ }^{2}$ Justus Liebig Universitat Giessen \\ ${ }^{3}$ Facultad de Veterinaria, Universidad Complutense
}

May 18, 2020

\begin{abstract}
Borna disease virus (BoDV) can cause neurological disease in several vertebrate species, especially in horses and sheep. The recent cases of fatal encephalitis caused by BoDV in humans have raised concern regarding the zoonotic character of this virus. BoDV infection in horses is endemic in Central Europe, whereas in Spain the disease is regarded as an exotic disease in horses and serological investigations in these animals have never been performed. The aim of this study was to investigate the exposure to BoDV in breeding and sport horses in Spain and to determine risk factors for the transmission of the virus. Serum samples from 495 horses (260 sport horses and 235 Spanish Purebred breeding horses) were tested by an Indirect Fluorescence Antibody Test (IFAT). From the SP breeding horses we examined factors putatively associated with seropositivity to BoDV. A total of 164 horses (33.1\%; 95\% CI 29.0-37.3) showed antibodies against BoDV. Factors associated with BoDV seropositivity in the SP breeding horses were climate, age and the time of the year when the horses were sampled. This is the first report on the presence of BoDV antibodies in apparently asymptomatic breeding and sport horses in Spain. Our results demonstrate the need for BoDV surveillance in horses and possible reservoir hosts in this country, and suggests that BoDV should be included in the differential diagnosis of equine and human cases of encephalitis.
\end{abstract}

First report of Borna disease virus antibodies in breeding and sport horses in Spain.

Fatima Cruz-Lopez $\mathrm{F}^{1^{*}}$, Susanne $\mathrm{Schmid}^{2,4}$, Eliazar Camino ${ }^{1,3}$, Friedemann Weber $^{2}$, Paloma Fores ${ }^{4}$, Sergio Gonzalez $^{1}$, Lucia de Juan ${ }^{1,3}$ and Matthias König ${ }^{2}$.

${ }^{1}$ VISAVET Health Surveillance Centre, Universidad Complutense de Madrid (Spain).

${ }^{2}$ Institute of Virology, Faculty of Veterinary Medicine, Justus Liebig University, Giessen, Germany.

${ }^{3}$ Departamento de Sanidad Animal, Facultad de Veterinaria, Universidad Complutense (Spain).

${ }^{3}$ Departamento de Medicina y Cirugía Animal, Facultad de Veterinaria, Universidad Complutense (Spain).

${ }^{4}$ Viro Vet Diagnostic Ltd., Giessen, Germany

${ }^{*}$ Corresponding author:

Address: VISAVET Health Surveillance Centre, Universidad Complutense de Madrid. Avda/ Puerta de Hierro, s/n, 28040, Madrid (Spain). Phone: +34 913944096 / fax: +34 913943975 / e-mail:

fatimacr@ucm.es

Running head: 
Borna disease virus in horses in Spain

\section{Summary}

Borna disease virus (BoDV) can cause neurological disease in several vertebrate species, especially in horses and sheep. The recent cases of fatal encephalitis caused by BoDV in humans have raised concern regarding the zoonotic character of this virus. BoDV infection in horses is endemic in Central Europe, whereas in Spain the disease is regarded as an exotic disease in horses and serological investigations in these animals have never been performed. The aim of this study was to investigate the exposure to BoDV in breeding and sport horses in Spain and to determine risk factors for the transmission of the virus. Serum samples from 495 horses (260 sport horses and 235 Spanish Purebred breeding horses) were tested by an Indirect Fluorescence Antibody Test (IFAT). From the SP breeding horses we examined factors putatively associated with seropositivity to BoDV. A total of 164 horses (33.1\%; 95\% CI 29.0-37.3) showed antibodies against BoDV. Factors associated with BoDV seropositivity in the SP breeding horses were climate, age and the time of the year when the horses were sampled. This is the first report on the presence of BoDV antibodies in apparently asymptomatic breeding and sport horses in Spain. Our results demonstrate the need for BoDV surveillance in horses and possible reservoir hosts in this country, and suggests that BoDV should be included in the differential diagnosis of equine and human cases of encephalitis.

Keywords

Borna disease virus; horse; serological survey; Spain.

Introduction

Borna disease (BD) is a sporadically occurring, usually fatal disorder caused by a neurotropic RNA virus, the Borna disease virus (BoDV) recently renamed as mammalian orthobornavirus (Rott and Becht, 1995, Richt, 2007, Heinig, 1969). Even though horses and sheep are the main natural hosts of BoDV, other Equidae , farm animals and companion animals (cats, dogs) have been diagnosed with natural BD infection (Richt, 2007, Staeheli et al., 2000). Furthermore, psittacine birds can be infected with an avian Bornavirus (PaBV, psittaciform orthobornavirus) associated with proventricular dilatation disease (Honkavuori et al., 2008).

The route of infection with BoDV occurs most likely via open nerve endings in the nasal and pharyngeal mucosa (Dürrwald et al., 2007, Priestnall et al., 2011). Shrews have been identified as carriers of the virus, whereas BoDV-infected horses do not seem to play a role in virus transmission (Nobach et al., 2015, Hilbe et al., 2006, Staeheli et al., 2000).

In horses, natural infection with BoDV can take an inapparent, subacute, acute or peracute course (Richt, 2007). The incubation period ranges from 2 to several months (Schmidt, 1952). Depending on the affected brain area, the clinical signs of classic BD in horses can range from changes in behaviour and consciousness to slow motion eating, fever, somnolence, stupor, hyperexcitability, or aggressiveness (Richt, 2007, Bilzer et al., 1996, Grabner and Fischer, 1991). Other signs of a more advanced stage in BD are hypokinesia, ataxia and hyporeflexia, leading to compulsive circular walking, head tremor, blindness, or convulsions and coma in final stages of the disease (Bilzer et al., 1996, Grabner and Fischer, 1991). The recent association of BoDV-1 with eight cases of fatal encephalitis in humans shows the zoonotic potential of the virus (Niller et al., 2020). The deaths of three people after a BoDV-1 infection, all of them solid organ recipients from a single donor, suggest another way of BoDV-1 transmission (Anon, 2018). While the zoonotic potential of $\mathrm{BoDV}$ is confirmed, its association with certain human psychiatric diseases remains controversial (Lieb and Staeheli, 2001, Staeheli and Lieb, 2001, Dürrwald et al., 2007).

BoDV infection in horses is endemic in Central Europe (Germany, Austria, Switzerland and Liechtenstein), while there are reports of sporadic clinical disease in other countries (Rott and Becht, 1995, Staeheli et al., 2000, Dürrwald et al., 2007).

In Spain, the only animals analysed for Bornavirus infection were captive birds (psittacines), which were tested for Avian Bornavirus (PaBV) (RNA, virus, antigen) and PaBV-specific antibodies (Heffels-Redmann 
et al., 2011); $14.3 \%$ of the samples were positive to PaBV. BoDV infection is currently regarded as an exotic disease in horses; however, serological investigations in these animals have never been performed.

Given this background, the present work aimed to carry out a serological survey on susceptible breeding and sport horses in Spain in order to retrospectively determine the degree of exposure to BoDV in asymptomatic horses and to determine risk factors for the exposure to BoDV in breeding horses.

\section{Materials and methods}

\section{Study area and sample collection:}

A total of 495 samples from healthy horses resident in 9 autonomous communities in Spain were investigated. We calculated the representative amount of samples considering a minimum of 385 horses that should be tested, using the formula for a finite population (Thrusfield et al., 2005) of 723,496 horses in Spain in 2012 (Ministerio de Agricultura, 2012, Deloitte, 2013), an expected prevalence of 50\%, with 95\% confidence and $5 \%$ precision. Table 1 shows the samples in detail: sera from 235 horses were randomly selected from Spanish Purebred (SP) breeding horses between September 2011 and November 2013 among those collected in previous serological studies carried out in central Spain (Cruz et al., 2015, Cruz et al., 2016a, Cruz et al., 2016b). We also tested 260 horse sera (70 breeding and 190 sport - dressage, showjumping, endurance or eventing) randomly selected among the sera sent from August 2015 to November 2016 to the Equine Health Surveillance Unit (SEVISEQ) in the Centre of Veterinary Health Surveillance (VISAVET - UCM) for pre-exportation analyses. Figure 1 represents the autonomous communities in Spain where the 495 horses were sampled.

For the SP horse samples, a questionnaire has been completed to gather information on the main characteristics and measures for the prevention and control of equine infectious diseases in the respective stud farm (Cruz et al., 2016a, Cruz et al., 2016b).

\section{Sample processing and serological analysis:}

Serum was obtained from blood after allowing clotting at room temperature for 2-5 hours, then centrifuged for 10 minutes at $1700 x \mathrm{~g}$ to separate the serum from the cellular fractions. Serum samples were aliquoted and frozen at $-20^{\circ} \mathrm{C}$ until subsequent analyses.

The IFAT was carried out according to the protocol in Viro Vet Diagnostik laboratory (Giessen, Germany). Noninfected Madine Darby canine kidney (MDCK) as well as MDCK cells persistently infected with BoDV H1766 (MDCK/-BoDV) were cultured for 3 to 4 days with medium produced in-house [4,5 g/l Dulbecco's Mo-

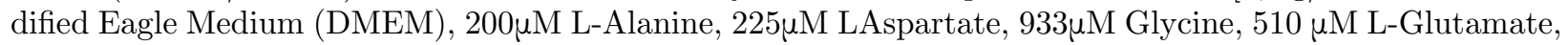
$217 \mu \mathrm{M}$, L-Proline, $184 \mu \mathrm{M}$, Hypoxanthine, $0,1 \mathrm{mg} / \mathrm{l}$ Biotine, 44mM NaHCO3] supplemented with $10 \%$ fetal bovine serum (FBS). Cells were trypsinized, suspended in the medium, diluted to a final amount of 10^ 6 cells / $\mathrm{ml}$ and spotted onto 10-well glass slides and cultured overnight. The slides were washed with PBS, fixed with anhydrous acetone at $-20^{\circ} \mathrm{C}$ for $2-4$ hours and dried. MDCK as well as MDCK/BoDV slides were incubated with horse sera diluted 1:10, 1:40, 1:160, 1:640 and 1:2560 in a humidity chamber at $37^{\circ} \mathrm{C}$ for 35 minutes. After three washes with PBS, Fluorescein isothiocyanate conjugated goat anti horse $\operatorname{IgG}$ (Dianova, Germany) was added to each well and the slide was incubated in a humidity chamber at $37^{\circ} \mathrm{C}$ for 35 minutes. The slides were washed with PBS and Aqua dd, mounted with PBS-glycerol under cover slips and examined for characteristic nuclear fluorescent pattern with a fluorescence microscope. The cut-off titre for a positive sample was 1:160, when the sample yielded no fluorescent pattern in the non-infected MDCK cell wells (Herzog, 1980). Titres of 1:10 to 1:40 are often considered questionable; however, they were regarded as negative for this study in order to easy the analysis of results.

\section{Statistical analyses:}

To evaluate the strength and direction of the associations of the horse and stud farm management risk factors with the seropositivity to BoDV by IFAT in the group of 235 SP breeding horses sampled between 2011 and 2013, a multivariable logistic regression model was carried out, after checking the independence of 
the stud farm factor. Odds ratios (ORs) with their corresponding $95 \%$ confidence intervals (CIs) were used to measure the associations. All analyses were performed with the software Small STATA version 12.0.

Possible risk factors were included as individual variables. The variables tested $(n=24)$ with their frequencies are listed in the Supplementary Data. All variables showing a $\mathrm{P}$ value $<0.25$ in the univariable screening analysis of variables controlling for important confounders (age) were selected for inclusion in a multivariable model, which included those confounders. The multivariable model was built using a stepwise backward variable selection procedure in which variables with a $\mathrm{P}<0.05$ were retained in the model, or where their removal resulted in a significant change in the effect of other variables indicating confounding. Collinearity between variables was checked and excluded. To improve the goodness of fit, biologically plausible firstorder interactions were determined between significant and confounders variables. The possible multivariable significant models were compared to each other by the Akaike Information Criterion (AIC) and the Bayesian Information Criterion (BIC) (Dohoo et al., 2003). The Hosmer-Lemeshow goodness-of-fit test (Hosmer, 2000) was used to evaluate the fitting of the proposed model and the area under the receiver operating characteristic (ROC) curve was also calculated.

Results

\section{Seroprevalence:}

A total of 495 serum samples were included in the serological screening to determine the occurrence of antibodies against BoDV in Spanish horses. The horses were resident in 9 autonomous communities (Figure 1). Sera were collected from 2011 to 2016, with the exception of 2014. Sampled horses included 54.9\% (272/495) males (geldings or stallions), 41.0\% (203/495) mares, and 4.0\% (20/495) samples with unknown sex. Breeding horses represented $61.6 \%$ of the sampled horses whereas the sport horse sera made up $38.4 \%$ of the samples. The majority of the horses were SP $(92.5 \%, 458 / 495)$. The results from the BoDV IFAT for the 495 horses are shown in Table 1.

A total of 164 horses (33.1\%; 95\% CI 29.0-37.3) showed antibodies specific to BoDV, with titres ranging from 1:160 to [?]1:2560 (Table 1). The vast majority of samples showed titres from 1:320 to 1:640 (85.4\%), with a $14.6 \%$ of samples showing a high titre of [?]1:2560. Figure 2 represents a positive IFAT on a horse with titre [?]1:2560.

Regarding the different sampling regions in Spain, there were no statistically significant differences $(\mathrm{p}=$ 0.87) between BoDV seroprevalences in those regions with a representative sampling (\% sampled horses > $0.1 \%$ of the total population residing in the autonomous community). Catalonia was the community with higher BoDV seroprevalence (41.7\%) followed by Murcia (36.8\%), Castille Leon (32.9\%), Castilla La Mancha (31.5\%), Madrid (31.0\%) and Extremadura (19.2\%).

BoDV seroprevalence was similar and there were no statistical differences in the two sampling periods $(\mathrm{p}=0.55)$ : samples collected in 2011-2013 showed a seroprevalence of $34.5 \%$ whereas samples collected in 2015-2016 showed a $31.9 \%$ seropositivity to BoDV.

Regarding seropositive samples by sex, 32.3\% (88/272) of male horses and 31.5\% (64/203) of mares had antibodies against BoDV.

Seroprevalence in breeding horses (35.4\%) was higher than in sport horses $(29.5 \%)$, although this difference was not statistically significant $(\mathrm{p}=0.17)$. Breeding horses sampled in 2011-2013 showed 34.5\% BoDV seropositives, and the seroprevalence in these horses increased to $38.6 \%$ in $2015-2016$, although this rise was also not statistically significant $(\mathrm{p}=0.53)$.

Factors associated with BoDV seropositivity in SP breeding horses:

Variables considered potentially associated with exposure to BoDV in the group of SP breeding horses sampled from 2011 to 2013 were included in a statistical model. The results of the final model and the effect of statistically significant variables $\left(\mathrm{p}_{\mathrm{i}} 0.05\right)$ are presented in Table 2. 
There was no clustering at the stud farm level, indicating that the between-stud variability was insufficient to warrant necessary incorporation of a stud farm-level random effect. The Hosmer-Lemeshow goodness-offit test indicated that the multivariable logistic regression model fitted the data adequately $(\mathrm{p}=0.85)$. The area under the ROC curve was 0.7 , indicating that the model had adequate overall predictive power. The main risk factor associated with seropositivity to BoDV was the presence of a cold semi-arid climate (BSK climate from the Köppen-Geiger Climate Classification) (Rubel and Kottek, 2010) in the area where the horse resided ( $\mathrm{OR}=3.04,95 \%$ CI 1.48 to 6.26$)$. Factors associated with decreased odds of being BoDV seropositive included the age and the time of the year when the horses were sampled. Adult horses, 7-14 years old, were 3.2 times less likely to be BoDV seropositive than young horses, 1- 6 years old ( $\mathrm{OR}=0.31,95 \%$ CI 0.16 to 0.63 ). Horses sampled from February to June were 2.7 times less likely to be BoDV seropositive than horses sampled from July to January (OR=0.37, 95\% CI 0.19 to 0.73 ).

\section{Discussion}

The present study aimed at providing a general picture of the exposure to BoDV in horses in Spain. The aim was to collect a representative sample of autonomous communities throughout the country. However, this was only possible in 5 of the 9 communities sampled, most of them in central Spain (a high risk area in terms of transmission of equine infectious diseases). This might be attributable to the fact that horses being exported to continental Europe or abroad often stop in central Spain (Cruz et al., 2016b) and because there the majority of national and international equestrian competitions are held (Deloitte, 2013).

Up to present BoDV causing clinical disease has never been reported in horses in Spain and the only information published is a case of an Appaloosa pony showing neurological signs and being seropositive to EHV-1 and BoDV. However in the latter case BoDV was not isolated and no molecular tests were carried out (Vitale et al., 2018). This is the first study to define BoDV seroprevalence in breeding and sport horses in Spain. Even though Spain was thought to be free from BoDV, our results showed that the virus may be endemic in this country. The determined seroprevalence (33.1\%; 95\% CI 29.0-37.3) was even higher than the seroprevalence in horses from areas with clinical disease in endemic countries like Germany $(22.5 \%)$ (Richt and Rott, 2001) or other countries like USA (2.7\%) (Kao et al., 1993), Finland (2.4\%) (Kinnunen et al., 2007), France (8.9\%) (Galabru et al., 2000) or Turkey (4.9\%) (Yesilbag et al., 2012). The high BoDV seroprevalence found in our study contrasts with the fact that no clinical cases have been reported up to date. This can be explained by subclinical infection (Richt, 2007) or misdiagnosed disease due to the fact that BoDV is not considered as a possible cause for neurological signs in horses in Spain. This report would suggest the need to test for BoDV in horses showing neurological signs, along with Equine Herpesvirus type 1 (EHV-1) or West Nile virus (WNV).

The seropositive horses in this study showed moderate to high titres, with up to $14.6 \%$ of seropositives presenting a titre of [?]1:2560. High titres have been restricted to clinical disease, and some reports have demonstrated that titres decrease relatively fast and are hardly detectable in a subacute or chronic disease (Dauphin and Zientara, 2001). The high titres shown by the horses in our study would therefore either suggest a recent (or frequent) exposure to BoDV or the fact that antibody titres against BoDV could remain high for a long time, in agreement with a study reported in Japan, where horses were found to be continuously seropositive for a period of four years (Inoue et al., 2002a). Further studies investigating possible hosts like shrews or other rodents would be necessary to corroborate a high prevalence of BoDV in them (Hilbe et al., 2006) which would enable a repeated exposure to BoDV in Spanish horses.

Regarding BoDV seroprevalence by autonomous community, no significant differences were found between the different sampled areas $(\mathrm{p}=0.87)$. The slight differences observed could be due to bias in sampling, and in order to establish an influence of the area on BoDV seroprevalence, a more extensive sampling covering all areas in Spain should be carried out. Furthermore, the population of shrews and other rodents in Spain should be investigated for the presence of the virus, in order to point out risk areas in Spain for this disease (Encarnacao et al., 2013).

The results of our study show that BoDV is endemic and stable through the years in Spain, since there were 
no significant differences between the seroprevalence in the two sampling periods (2011-2013 and 2015-2016) $(\mathrm{p}=0.55)$. Breeding horses sampled in both periods showed a slight increase in the seroprevalence in 20152016 , although this increase was not significant $(\mathrm{p}=0.53)$ and could be a reflection of BoDV dynamics or fluctuation in wild rodents (Richt, 2007, Encarnacao et al., 2013, Kinnunen et al., 2013).

Similarly to other studies, our results determined that BoDV seropositivity was not associated to sex $(\mathrm{p}=$ 0.85) (Inoue et al., 2002b, Inoue et al., 2002a). The only study that found a higher seroprevalence in female horses was carried out in Italy using circulating immunocomplexes (CIC) ELISA tests, which are not considered the gold standard test for BoDV diagnosis (Pisoni et al., 2007).

Even though we did not find statistically significant differences $(\mathrm{p}=0.17)$, seroprevalence in breeding horses (which are often kept in the field) was higher than in sport horses (kept in stables). Further studies would be necessary to prove or exclude this association, since several studies have found higher BoDV seroprevalence rates in stabled horses, probably associated to a higher presence of reservoir hosts (Richt, 2007, Inoue et al., 2002b). A higher presence of the virus in breeding horses, already seen by Pisoni et al. (2007) in Italy would entail the need to investigate this population and the reservoir hosts present in the fields of Spain, since the risk of vertical transmission of the virus and the occurrence of abortion has been documented in the literature (Hagiwara et al., 2000).

In the population of breeding horses of our study, factors associated to BoDV seropositivity were the climate, the age and the time of the year when the horses were sampled (Table 2). Horses residing in an area with a cold semi-arid climate (BSK climate from the Koppen-Geiger Climate Classification) (Rubel and Kottek, 2010) were 3 times more likely to be BoDV seropositive. This factor has already been reported elsewhere, and is probably related to the living conditions for reservoir hosts, which prefer a cold climate with low precipitations (Encarnacao et al., 2013).

Our results showed a lower seropositivity in adult horses ( 7 to 14 years old) (OR=0.31, 95\% CI 0.16 to 0.63 ) and in older horses (15 to 24 years old) compared to young horses (1 to 6 years old), However the decrease was not significant in the oldest horses $(\mathrm{p}=0.69)$. In contrast other viruses like Equine Viral Arteritis virus or EHV-1 showed a higher seroprevalence in older individuals in the same population (Cruz et al., 2016a, Cruz et al., 2016b). In addition, other BoDV studies showed no association between age and seropositivity rate (Pisoni et al., 2007, Inoue et al., 2002b). The decrease in the seroprevalence in older individuals could be related to a decrease in the antibody titres after infection, suggesting that SP breeding horses would be infected in the early years, when they are in the field, and not in stables.

The literature has shown that BoDV clinical disease peaks in the period between March and June due to infection during the autumn-winter when the horses are stabled (Richt, 2007, Kinnunen et al., 2013, Durrwald and Ludwig, 1997), and that antibodies rise late in the course of infection, along with clinical disease (Richt et al., 2000). However, in our study, the breeding horses sampled from February to June (supposedly the period associated to clinical disease and high antibody titres) were 2.7 times less likely to be BoDV seropositive than horses sampled from July to January ( $\mathrm{OR}=0.37,95 \%$ CI 0.19 to 0.73). This is interesting and agrees with the idea that, in Spain, breeding SP horses would be more likely to encounter BoDV when they are young, and while they are out in the fields during the spring-summer, showing a rise in their antibodies during the autumn-winter. Therefore, further studies in order to characterise BoDV reservoir hosts may help to elucidate BoDV transmission in horses in Spain.

Given the recent association of BoDV-1 with eight cases of fatal encephalitis in humans in areas of BoDV endemicity in Germany (Niller et al., 2020), our results would rise the concern regarding the zoonotic potential of this virus in Spain; therefore, BoDV should be included in the differential diagnosis of encephalitis in humans.

In conclusion, the present study provides the first report on the endemicity of BoDV in apparently asymptomatic breeding and sport horses in Spain. We suggest that Borna Disease should be considered as a differential diagnosis to Equine Herpesvirus Myeloencephalopathy or West Nile of a horse suffering from neurological symptoms, and that human cases of encephalitis should also be tested for BoDV. Epidemiolog- 
ical studies at the local levels are paramount to forecast disease risks and understand the transmission and the reservoir hosts involved, in order to implement preventive measures.

\section{Acknowledgements}

The authors wish to thank the owners and the veterinary surgeons of the studs included in the study for their valuable help, and the technicians at the VISAVET Health Surveillance Centre (UCM, Madrid) and Viro-Vet Diagnostik (Institute of Virology, Justus Liebig University, Giessen) for their work.

\section{Ethical Statement}

The authors confirm that the ethical policies of the journal, as noted on the journal's author guidelines page, have been adhered to. No ethical approval was required as this is a retrospective study carried out with serum samples drawn for other purposes where an informed consent document for the use of these samples in this study was signed.

\section{Conflict of Interest Statement}

The authors declare no conflict of interest in the subject, matter or materials discussed in this manuscript.

Data availability Statement

The data from this study will be made available upon request.

\section{References}

ANON 2018. Acute encephalitis associated with infection with Borna disease virus 1 - Germany. Stockholm: ECDC: European Centre for Disease Prevention and Control.

BILZER, T., GRABNER, A. \& STITZ, L. 1996. Immunopathology of Borna disease in the horse: clinical, virological and neuropathologic findings. Tierarztl Prax, 24, 567-76.

CRUZ, F., FORES, P., IRELAND, J., MORENO, M. A. \& NEWTON, R. 2015. Freedom from equine infectious anaemia virus infection in Spanish Purebred horses. Vet Rec Open, 2, e000074.

CRUZ, F., FORES, P., MUGHINI-GRAS, L., IRELAND, J., MORENO, M. A. \& NEWTON, J. R. 2016a. Seroprevalence and factors associated with equine herpesvirus type 1 and 4 in Spanish Purebred horses in Spain. Vet Rec, 178, 398.

CRUZ, F., FORES, P., MUGHINI-GRAS, L., IRELAND, J., MORENO, M. A. \& NEWTON, R. 2016b. Seroprevalence and factors associated with seropositivity to equine arteritis virus in Spanish Purebred horses in Spain. Equine Vet J, 48, 573-7.

DAUPHIN, G. \& ZIENTARA, S. 2001. Evidence of Borna disease virus in france. Epidemiologie Et Sante Animale, 63-71.

DELOITTE 2013. Estudio del Impacto del Sector Ecuestre en Espana. Real Federacion Hipica Espanola.

DOHOO, I., MARTIN, W. \& STRYHN, H. 2003. Veterinary Epidemiologic Research., Charlottetown, Prince Edward Island, Canada, Atlantic Veterinary College, University of Prince Edward Island.

DURRWALD, R., KOLODZIEJEK, J., HERZOG, S. \& NOWOTNY, N. 2007. Meta-analysis of putative human bornavirus sequences fails to provide evidence implicating Borna disease virus in mental illness. Rev Med Virol, 17, 181-203.

DURRWALD, R. \& LUDWIG, H. 1997. Borna disease virus (BDV), a (zoonotic?) worldwide pathogen. A review of the history of the disease and the virus infection with comprehensive bibliography. Journal of Veterinary Medicine Series B-Infectious Diseases and Veterinary Public Health, 44, 147-184. 
ENCARnACAO, J. A., HERZOG, S., EICKMAnN, M., BECKER, N. I., HERMES, N. \& HERDEN, C. 2013. Landscape Features and Reservoir Occurrence Affecting the Risk for Equine Infection with Borna Disease Virus.Journal of Wildlife Diseases, 49, 860-868.

GAlABRU, J., SARON, M. F., BERG, M., BERG, A. L., HERZOG, S., LABIE, J. \& ZIENTARA, S. 2000. Borna disease virus antibodies in French horses. Veterinary Record, 147, 721-722.

GRABNER, A. \& FISCHER, A. 1991. Symptomatology and diagnosis of Borna encephalitis of horses. A case analysis of the last 13 years. Tierarztl Prax, 19, 68-73.

HAGIWARA, K., KAMITANI, W., TAKAMURA, S., TANIYAMA, H., NAKAYA, T., TANAKA, H., KIRISAWA, R., IWAI, H. \& IKUTA, K. 2000. Detection of Borna disease virus in a pregnant mare and her fetus. Veterinary Microbiology, 72, 207-216.

HefFels-Redmann, U., ENDERlein, D., HERzOG, S., HERDEN, C., PIEPENBRING, A., NEUMANN, D., MULLER, H., CAPELLI, S., MULLER, H., OBERHAUSER, K., GERLACH, H., KALETA, E. F. \& LIERZ, M. 2011. Occurrence of avian bornavirus infection in captive psittacines in various European countries and its association with proventricular dilatation disease.Avian Pathology, 40, 419-426.

HEINIG, A. 1969. Die Bornasche Krankheit der Pferde und Schafe.

Handbuch der Virusinfektionen bei Tieren.

HERZOG, S. 1980. Replication of Borna Disease Virus in Cell-Cultures.Zentralblatt Fur Bakteriologie Mikrobiologie Und Hygiene Series a-Medical Microbiology Infectious Diseases Virology Parasitology,248, 22-22.

HILBE, M., HERRSCHE, R., KOLODZIEJEK, J., NOWOTNY, N., ZLINSZKY, K. \& EHRENSPERGER, F. 2006. Shrews as reservoir hosts of borna disease virus.Emerg Infect Dis, 12, 675-7.

HONKAVUORI, K. S., SHIVAPRASAD, H. L., WILliAMS, B. L., QUAN, P. L., HORNIG, M., STREET, C., PAlacios, G., HUtChison, S. K., FRAnCA, M., EGHOlM, M., BRIESE, T. \& LiPKIN, W. I. 2008. Novel borna virus in psittacine birds with proventricular dilatation disease. Emerg Infect Dis, 14, $1883-6$.

HOSMER, D. W., LEMESHOW, S., 2000. Applied Logistic Regression.Second Ed. Wiley Interscience Press, New York, USA ,pp.143-188.

INOUE, Y., YAMAGUCHI, K., SAWADA, T., RIVERO, J. C. \& HORII, Y. 2002a. Demonstration of continuously seropositive population against Borna disease virus in Misaki feral horses, a Japanese strain: a four-year follow-up study from 1998 to 2001. Journal of Veterinary Medical Science, 64, 445-448.

INOUE, Y., YAMAGUCHI, K., SAWADA, T., RIVERO, J. C. \& HORII, Y. 2002b. Higher prevalence of anti-Borna disease virus antibodies in stabled than in feral horses in Japan. Equine Veterinary Journal, 34,741-743.

KAO, M., HAMIR, A. N., RUPPRECHT, C. E., FU, Z. F., SHANKAR, V., KOPROWSKI, H. \& DIETZSCHOLD, B. 1993. Detection of Antibodies against Borna Disease Virus in Sera and Cerebrospinal-Fluid of Horses in the USA. Veterinary Record, 132, 241-244.

KINNUNEN, P. M., BILliCH, C., EK-KOMMONEN, C., HENTTONEN, H., KALLIO, E. R. K., NIEMIMAA, J., PALVA, A., STAEHELI, P., VAHERI, A. \& VAPALAHTI, O. 2007. Serological evidence for Borna disease virus infection in humans, wild rodents and other vertebrates in Finland. Journal of Clinical Virology, 38, 64-69.

KINNUNEN, P. M., PALVA, A., VAHERI, A. \& VAPALAHTI, O. 2013. Epidemiology and host spectrum of Borna disease virus infections. Journal of General Virology, 94, 247-262.

LIEB, K. \& STAEHELI, P. 2001. Borna disease virus-does it infect humans and cause psychiatric disorders? J Clin Virol,21, 119-27. 
MINISTERIO DE AGRICUlTURA, A. Y. M. 2012. Programa ARCA. 31st December 2012 ed.

NilleR, H. H., ANGSTWURM, K., RUBBEnStroth, D., SCHLOTTAU, K., EBINGER, A., GIESE, S., WUNDERLICH, S., BANAS, B., FORTH, L. F., HOFFMANN, D., HOPER, D., SCHWEMMLE, M., TAPPE, D., SCHMIDT-CHANASIT, J., NOBACH, D., HERDEN, C., BROCHHAUSEN, C., VELEZCHAR, N., MAMILOS, A., UTPATEL, K., EVERT, M., ZOUBAA, S., RIEMENSCHNEIDER, M. J., RUF, V., HERMS, J., RIEDER, G., ERRATH, M., MATIASEK, K., SCHLEGEL, J., LIESCHE-STARNECKER, F., NEUMANN, B., FUCHS, K., LINKER, R. A., SALZBERGER, B., FREILINGER, T., GARTNER, L., WENZEL, J. J., REISCHL, U., JILG, W., GESSNER, A., JANTSCH, J., BEER, M. \& SCHMIDT, B. 2020. Zoonotic spillover infections with Borna disease virus 1 leading to fatal human encephalitis, 1999-2019: an epidemiological investigation. Lancet Infect Dis,20, 467-477.

NOBACH, D., BOURG, M., HERZOG, S., LANGE-HERBST, H., ENCARNACAO, J. A., EICKMANN, M. \& HERDEN, C. 2015. Shedding of Infectious Borna Disease Virus-1 in Living Bicolored White-Toothed Shrews. PLoS One,10, e0137018.

PISONI, G., NATIVI, D., BRONZO, V. \& CODAZZA, D. 2007. Sero-epidemiological study of Borna disease virus infection in the Italian equine population. Veterinary Research Communications,31, 245-248.

PRIESTNALL, S. L., SCHONIGER, S., IVENS, P. A., EICKMANN, M., BRACHTHAUSER, L., KEHR, K., TUPPER, C., PIERCY, R. J., MENZIES-GOW, N. J. \& HERDEN, C. 2011. Borna disease virus infection of a horse in Great Britain. Vet Rec, 168, 380b.

RICHT, J. A., GRABNER, A. \& HERZOG, S. 2000. Borna disease in horses. Vet Clin North Am Equine Pract, 16, 579-95, xi.

RICHT, J. A., GRABNER, A., HERZOG, S., GARTEN, W., AND HERDEN, C. 2007. Borna disease in equines. In: D.C. SELLON, M. L. (ed.)Equine Infectious Diseases. St. Louis.: Saunders Elsevier.

RICHT, J. A. \& ROTT, R. 2001. Borna disease virus: a mystery as an emerging zoonotic pathogen. Veterinary Journal, 161,24-40.

ROTT, R. \& BECHT, H. 1995. Natural and experimental Borna disease in animals. Curr Top Microbiol Immunol, 190, 17-30.

RUBEL, F. \& KOTTEK, M. 2010. Observed and projected climate shifts 1901-2010 depicted by world maps of the Koppen-Geiger climate classification. Meteorol. Z., 19, 135-141.

SCHMIDT, J. 1952. Die Bornakrankheit des Pferdes: 55 Jahre Forschung und Lehre. Archiv fur Experimentelle Veterinarmedizin, 6,177-187.

STAEHELI, P. \& LIEB, K. 2001. Bornavirus and psychiatric disorders - fact or fiction? J Med Microbiol, $50,579-81$.

STAEHELI, P., SAUDER, C., HAUSMANN, J., EHRENSPERGER, F. \& SCHWEMMLE, M. 2000. Epidemiology of Borna disease virus. J Gen Virol,81, 2123-2135.

THRUSFIELD, M., MANSLEY, L., DUNLOP, P., PAWSON, A. \& TAYLOR, J. 2005. The foot-and-mouth disease epidemic in Dumfries and Galloway, 2001. 2: Serosurveillance, and efficiency and effectiveness of control procedures after the national ban on animal movements. Veterinary Record,156, 269-+.

VITALE, V., LOPEZ-ATAlayA, M. M., VIU, J., ARMENGOU, L. \& CUNILLERAS, E. J. 2018. Coinfeccion por Herpesvirus-1 y Bornavirus en un poni en el Noreste de Espana. VII Congreso Anual de la A.V.E.E. de Espana.Alicante, Spain.

YESILBAG, K., HERZOG, S., KENNERMAN, E., TUNCER, P., SCHMID, S., KAYA, G. \& THIEL, H. J. 2012. Serological evidence for infections with Borna disease virus in Turkey. Berliner Und Munchener Tierarztliche Wochenschrift, 125, 452-455. 


\section{Figure captions}

Figure 1. Spanish autonomous communities participating in the study and number of samples (N) received from each of them, presented as color code. BoDV seroprevalence is represented in pie charts, only for the autonomous communities with a sampling rate $>0.10 \%$.

Figure 2. IFAT on MDCK cells infected with BoDV (MDCK-BoDV) in a seropositive horse with a titre of $[?] 1: 2560$.

\section{Tables}

Table 1. Number of breeding/sport horses included in the study and results of the IFAT with the titre for the two sampling periods.

Table 2. Output of the final multivariable logistic regression model of risk factors for BoDV in SP breeding horses ( $\mathrm{n}=235 ; 81$ seropositive and 154 seronegative).

\section{Hosted file}

Table 1 Borna paper.docx available at https://authorea.com/users/322731/articles/451680first-report-of-borna-disease-virus-antibodies-in-breeding-and-sport-horses-in-spain

\section{Hosted file}

Table 2 Borna paper.docx available at https://authorea.com/users/322731/articles/451680first-report-of-borna-disease-virus-antibodies-in-breeding-and-sport-horses-in-spain

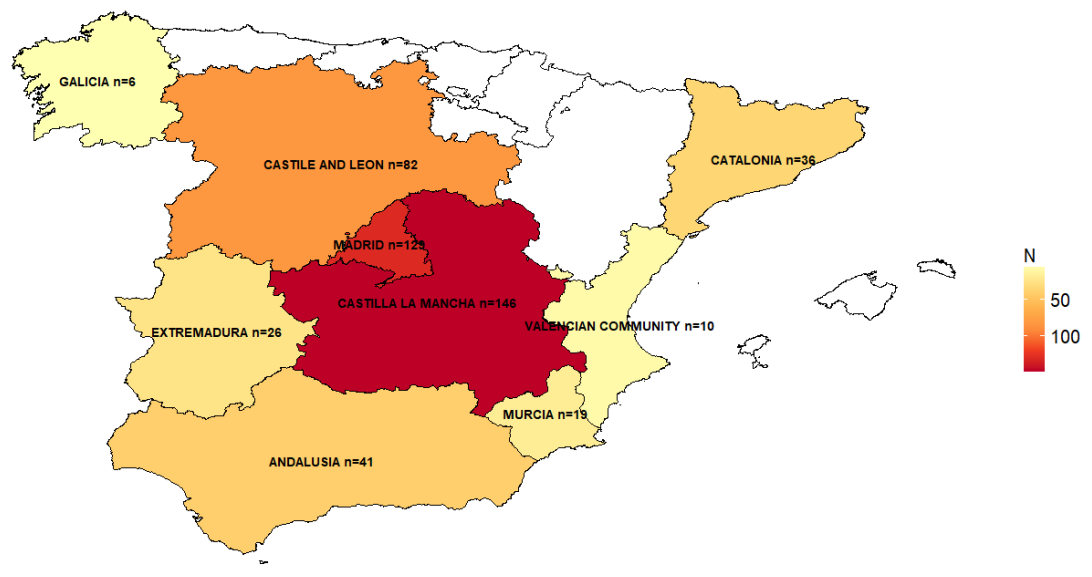




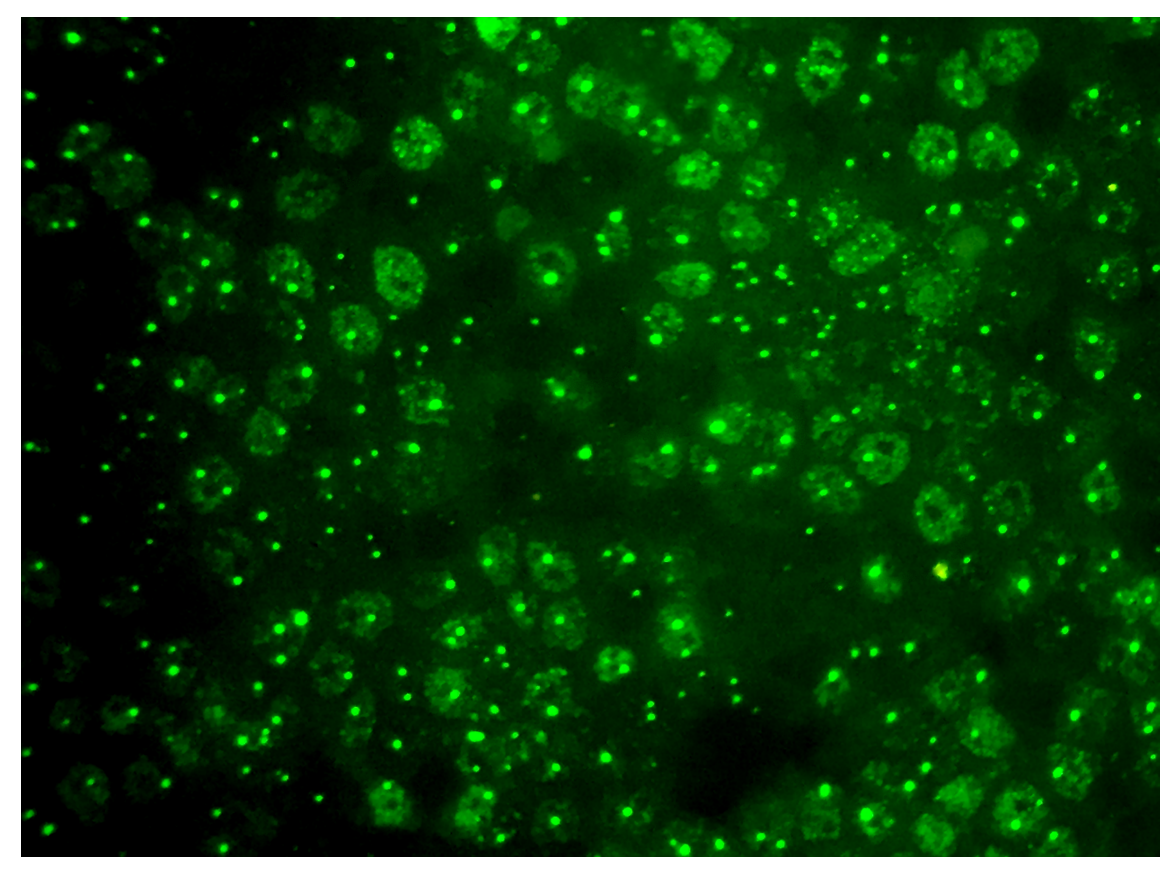

